BBA 21842

\title{
DIFFERENCES IN THE EFFECT OF ARACHIDONIC ACID ON POLYMORPHONUCLEAR AND MONONUCLEAR LEUKOCYTE FUNCTION
}

\author{
PAUL A.J. HENRICKS a MARIJKE E. VAN DER TOL ", J. HENNY VAN KATS-RENAUD ", \\ FRANS P. NIJKAMP ${ }^{b}$ and JAN VERHOEF ${ }^{a}$ \\ "Laboratory of Microbiology, Catharijnesingel 59, 3511 GG Utrecht, and" Institute of Veterinary Pharmacologi, Pharmacy \\ and Toxicology, State University of Utrecht, Biltstraat 172. 3572 BP Utrecht (The Netherlands)
}

(Received March 26th, 1984)

Key words: Arachidonate; Phagocyte function; (Human neutrophil, Monocyte)

Incubation of human polymorphonuclear leukocytes with arachidonic acid resulted in a stimulation of the oxidative metabolism of the cells. Upon stimulation with $80 \mu \mathrm{M}$ arachidonic acid, neutrophils $\left(5 \cdot 10^{6}\right.$ cells $/ \mathrm{ml}$ ) produced superoxide $\left(53 \pm 8 \mathrm{nmol} / 5 \cdot 10^{6}\right.$ cells per $\left.15 \mathrm{~min}\right)$, generated chemiluminescence $(1211100 \pm 157000 \mathrm{cpm})$ and consumed oxygen $\left(20 \pm 1 \mathrm{nmol} / 1^{6}\right.$ cells per $\left.5 \mathrm{~min}\right)$. The stimulation of the cell metabolism could be reduced $40-60 \%$ by prior incubation of the cells with $10 \mu \mathrm{M}$ indomethacin. Incubating polymorphonuclear leukocytes with arachidonic acid also resulted in a diminished chemotaxis towards an attractant, a decreased uptake of opsonized staphylococci and aggregation of the cells. This may be due to inhibitory products of arachidonic acid metabolism and toxic oxygen species produced during stimulated oxidative metabolism. The effects of arachidonic acid are specific for neutrophils, as mononuclear phagocytes only produced $17 \pm 8 \mathrm{nmol}$ superoxide $/ 5 \cdot 10^{6}$ cells per $15 \mathrm{~min}$ and generated $27000 \pm 15000$ cpm chemiluminescence when stimulated with $80 \mu \mathrm{M}$ arachidonic acid. When monocytes and neutrophils were stimulated with particles such as opsonized staphylococci, the amount of superoxide produced, oxygen consumed and chemiluminescence generated were similar. The phagocytic activity of the monocytes was also not affected by prior incubation with arachidonic acid. We conclude that in contrast to monocytes, neutrophil metabolism can be stimulated with arachidonic acid and this stimulation resulted in a decreased phagocytic activity of these cells.

\section{Introduction}

The process of phagocytosis of microorganisms by polymorphonuclear leukocytes and mononuclear phagocytes can be separated into four distinct, but interrelated, phases: chemotaxis, opsonization, ingestion and killing [1,2]. Phagocytosis is accompanied by a burst in oxygen consumption, hexose monophosphate shunt activity and formation of activated toxic oxygen species $[1,3,4]$. Phagocytosis is also associated with a decrease in the amount of arachidonic acid in the phospholipid fraction of the phagocytic vacuole membranes [5] and by an increased production of prostaglan- dins and leukotrienes [6-8]. Release of arachidonic acid from the cell membrane is a result of membrane perturbations, which can be brought about by, for example, inflammatory or immunological stimuli [7-10], calciumionophores [11] or mechanical agitation [12]. Arachidonic acid can be oxygenated by cyclooxygenase to form prostaglandin $G_{2}$, which can be converted to the other prostaglandins and thromboxanes and by lipoxygenases to form hydroperoxyeicosatetraenoic acids, which can be metabolized to either analogous hydroxyeicosatetraenoic acids or leukotrienes $[13,14]$. Leukotriene $B_{4}$ [15], several monohydroxyeicosatetraenoic acids [16] and prostaglandin $E_{1}[6]$ are 
chemotactic for neutrophils. Arachidonic acid metabolites may play a role in the process of aggregation and adhesiveness of neutrophils $[15,17]$. Also, arachidonic acid itself affects the function of phagocytic cells. When neutrophils were incubated with this acid, cells aggregate [18] produce superoxide [19] and generate chemiluminescence [20].

We have examined the effects of exogenous arachidonic acid on several human polymorphonuclear and mononuclear leukocyte functions. It was found that, in contrast to neutrophils, monocyte metabolism was not stimulated by arachidonic acid. The acid decreased chemotactic and phagocytic activity of neutrophils, but not of monocytes. This work has been presented in part at the 22nd Interscience Conference on Antimicrobial Agents and Chemotherapy, Miami Beach, Florida, U.S.A., 4-6 October 1982 (Abstract 735) and the 17th Annual Meeting of the European Society for Clinical Investigation, Travemünde, F.R.G., 21-23 April 1983 (Abstract 205).

\section{Materials and Methods}

Materials. Arachidonic acid (5,8,11,14-eicosatetraenoic acid, porcine liver grade 1, Sigma, St. Louis, MO) and indomethacin (Merck, Sharpe \& Dohme BV, Haarlem, The Netherlands) were prepared as described previously [21]. Luminol (5amino-2,3-dihydro-1,4-phthalazinedione; Sigma) was prepared in a $1.5 \mathrm{mM}$ stock solution in dimethylsulfoxide. Ferricytochrome $c$ (horse heart type VI), superoxide dismutase (E.C. 1.15.1.1.; bovine liver) and catalase (E.C. 1.11.1.6) were obtained from Sigma. All these reagents were dissolved and diluted in Hanks' balanced salt solution, containing $0.1 \%$ gelatin (Gibco Biocult, Paisley, U.K.). Dextran ( $\left.M_{\mathrm{r}} 70000\right)$, Percoll and Ficoll-Paque were obtained from Pharmacia Fine Chemicals AB, Uppsala, Sweden. Staphylococcus aureus $\mathrm{Ev}$, a clinical isolate, was prepared as described previously [22]. The bacteria were opsonized in human pooled serum and diluted in Hanks' balanced salt solution with $0.1 \%$ gelatin by incubating on a rotator for $30 \mathrm{~min}$ at $37^{\circ} \mathrm{C}$ [22].

Preparation of leukocyte suspensions. Polymorphonuclear leukocytes and mononuclear phagocytes were isolated from heparinized venous blood from healthy volunteers by dextran sedimentation of erythrocytes, differential density centrifugation on Ficoll-Paque, and $\mathrm{NH}_{4} \mathrm{Cl}$ lysis of contaminating erythrocytes [22,23]. The leukocyte suspensions were adjusted to a concentration of $5 \cdot 10^{6}$ or $1 \cdot 10^{7}$ cells $/ \mathrm{ml}$ Hanks' medium. For some studies, neutrophils were obtained from a female patient with well-defined chronic granulomatous disease of childhood.

Monocyte suspensions contained $70-75 \%$ lymphocytes and were further purified using the rate zonal centrifugation method [24] modified by Dr. A.C. Bloem (Department of Clinical Immunology, University Hospital Utrecht, The Netherlands). $1 \cdot 10^{7}$ monocytes were centrifuged for $10 \mathrm{~min}$ at $160 \times g$, and the supernatant solution was discarded and resuspended in $1 \mathrm{ml} 90 \%(\mathrm{v} / \mathrm{v})$ Percoll ( 9 parts of Percoll mixed with 1 part of 10 times concentrated phosphate-buffered saline). 2-ml aliquots of 70,60 and 30\% Percoll solutions were layered over the $90 \%$ solution. The gradient was centrifuged for $5 \mathrm{~min}$ at $160 \times \mathrm{g}$, and the cells at the interface between 30 and $60 \%$ Percoll were carefully removed and washed twice. The obtained cell suspensions contained 85-95\% monocytes.

Determinations of oxygen metabolism. Leukocytes $\left(5 \cdot 10^{6}\right.$ cells) were stimulated with $2.5 \cdot 10^{8}$ colony-forming units of opsonized (5\% serum) $S$. aureus or with 40,80 or $160 \mu \mathrm{M}$ arachidonic acid in a total volume of $1 \mathrm{ml} \mathrm{Hanks'}$ medium at $37^{\circ}$. Chemiluminescence was carried out in the presence of $0.1 \mathrm{ml}$ luminol $(0.3 \mu \mathrm{M})$ in a liquid scintillation counter in out-of-coincidence mode $[25,26]$. Superoxide formation was determined as the superoxide dismutase-sensitive reduction of ferricytochrome $c[26,27]$. Oxygen consumption was measured with a Clark electrode (model YSI 5331, Yellow Springs Instruments, Yellow Springs, $\mathrm{OH}$ ) [28]. In some experiments, neutrophils were incubated with indomethacin for $10 \mathrm{~min}$ at $37^{\circ} \mathrm{C}$, before adding arachidonic acid.

Quantitation of phagocytosis. $0.1 \mathrm{ml}$ leukocyte suspensions $\left(1 \cdot 10^{7}\right.$ cells $\left./ \mathrm{ml}\right)$ were incubated at $37^{\circ} \mathrm{C}$ with $0.1 \mathrm{ml}$ arachidonic acid solutions $(0,80$ or $160 \mu \mathrm{M}$ ) in poly(propylene)biovials (Biovials, Beckman, Chicago, IL). After $10 \mathrm{~min}$, the vials were placed in ice/water, and $0.2 \mathrm{ml}$ pre-opsonized (5\% serum) radiolabeled $S$. aureus suspension (5. $10^{7}$ bacteria $/ \mathrm{ml}$ ) was added to each vial and in- 
cubated again for 2,6 or $12 \min$ at $37^{\circ} \mathrm{C}$ to study phagocytosis [29]. In some experiments, polymorphonuclear leukocytes were incubated with arachidonic acid in the presence of ferricytochrome $c$, superoxide dismutase, catalase, thiourea, cyanide or indomethacin.

Chemotactic activity. $5 \cdot 10^{6}$ leukocytes were incubated with 0,40 or $80 \mu \mathrm{M}$ of arachidonic acid for $10 \mathrm{~min}$ at $37^{\circ} \mathrm{C}$. The leukocytes were centrifuged at $160 \times \mathrm{g}$ for $5 \mathrm{~min}$ and resuspended in 0.1 $\mathrm{ml}$ Eagle's minimum essential medium $\left(5 \cdot 10^{7}\right.$ cells $/ \mathrm{ml}$ ), and chemotactic activity was determined using the under-agarose technique $[30,31]$. In previous experiments, no differences were observed between a 4 or $18 \mathrm{~h}$ incubation of the agarose plates. Therefore, for convenience, migration distance was read after $18 \mathrm{~h}$ incubation.

Determination of enzyme activities. Leukocytes $\left(5 \cdot 10^{6} / \mathrm{ml}\right)$ were incubated with 40,80 or $160 \mu \mathrm{M}$ arachidonic acid or with $2.5 \cdot 10^{8}$ colony-forming units $S$. aureus (opsonized in 5\% serum) in a total volume of $1 \mathrm{ml}$ for $10 \mathrm{~min}$ at $37^{\circ} \mathrm{C}$. The incubations were stopped with $2.5 \mathrm{ml}$ ice-cold phosphatebuffered saline and the leukocytes were centrifuged at $160 \times \mathrm{g}$ for $10 \mathrm{~min}$. Triton X-100 (BDH Chemicals, Poole, U.K.) solution was added to the pellet. After sonication for $2 \times 10 \mathrm{~s}$ at $0^{\circ} \mathrm{C}$, the suspensions were centrifuged at $12000 \times g$ for 10 min, and the supernatant fluids were used for enzyme determinations. $\beta$-Glucuronidase (EC 3.2.1.31) was assayed using $p$-nitrophenyl- $\beta$-Dglucuronide (Koch-Light Laboratories, Colnbrook, U.K.) as substrate [32]. Lactate dehydrogenase (EC 1.1.1.27) was determined spectrophotometrically at $366 \mathrm{~nm}$ by measuring the reduction of NADH by pyruvate [33].

Leukocyte aggregation. $5 \cdot 10^{6}$ leukocytes were allowed to equilibrate to $37^{\circ} \mathrm{C}$ in an aggregometer tube. The cells were stimulated with $160 \mu \mathrm{M}$ arachidonic acid or with $2.5 \cdot 10^{8}$ opsonized staphylococci, and the decrease in light scattering, due to aggregation, was monitored at $609 \mathrm{~nm}$ [26]. The aggregometer/recorder system was calibrated with a granulocyte suspension diluted $1: 3$.

Malonyldialdehyde formation. $4 \cdot 10^{7}$ neutrophils were mixed with 40,80 or $160 \mu \mathrm{M}$ arachidonic acid or $4 \cdot 10^{8}, 1 \cdot 10^{9}$ or $2 \cdot 10^{9}$ colony-forming units $S$. aureus (opsonized in 5\% serum) in a total volume of $1 \mathrm{ml}$ and incubated at $37^{\circ} \mathrm{C}$ for $1 \mathrm{~h}$.
The formation of malonyldialdehyde was assayed, according to the method of Smith et al. [34].

Statistical analysis. Results have been expressed as the mean of three or more independent observations \pm S.D. For significance analysis, Student's $t$-test was performed. $P$ values exceeding 0.05 were considered not significant.

\section{Results}

Effect of arachidonic acid on superoxide production by phagocytic cells

Superoxide production by polymorphonuclear and mononuclear phagocytes was determined by measuring the amount of ferricytochrome $c$ reduction. The leukocytes were stimulated with various amounts of arachidonic acid and with opsonized staphylococci (Table I). Differences between neutrophils and monocytes in superoxide formation were found when the leukocytes were stimulated with arachidonic acid (Table I). Even when using very large amounts of arachidonic acid $(1.6 \mathrm{mM})$ to stimulate the cells, monocytes still produced less superoxide than neutrophils $(35 \pm 8$ vs. $72 \pm 3$ nmol $\mathrm{O}_{2}^{-} / 5 \cdot 10^{6}$ cells per $\left.15 \mathrm{~min}, P<0.001\right)$. In contrast to the effect of arachidonic acid, no significant differences between monocytes and neutrophils were found when the leukocytes were stimulated with opsonized $S$. aureus (Table I). The

\section{TABLE I}

EFFECT OF DIFFERENT STIMULI ON SUPEROXIDE PRODUCTION BY PHAGOCYTIC CELLS

$5 \cdot 10^{6}$ leukocytes were incubated with $0.1 \mathrm{ml}$ ferricytochrome $c$ $(0.9 \mathrm{mM})$ and with arachidonic acid $(n=6)$ or with opsonized staphylococci $(n=4)$ for $15 \mathrm{~min}$ at $37^{\circ} \mathrm{C}$. After removal of the cells and bacteria by centrifugations, the amount of superoxide produced was determined by measuring the absorption of the mixture at $550 \mathrm{~nm}$.

\begin{tabular}{llc}
\hline & \multicolumn{2}{l}{$\begin{array}{l}\text { Superoxide production (nmol } \\
\mathrm{O}_{2}^{-} / 5 \cdot 10^{6} \text { cells per 15 min) }\end{array}$} \\
\cline { 2 - 3 } & neutrophils & monocytes \\
\hline $40 \mu \mathrm{M}$ arachidonic acid & $10 \pm 2$ & $8 \pm 7$ \\
$80 \mu \mathrm{M}$ arachidonic acid & $53 \pm 8$ & $17 \pm 8^{\mathrm{a}}$ \\
$160 \mu \mathrm{M}$ arachidonic acid & $57 \pm 10$ & $29 \pm 9^{\mathrm{b}}$ \\
$2.5 \cdot 10^{8}$ S. aureus & $42 \pm 3$ & $42 \pm 6$ \\
\hline
\end{tabular}

$P$ values compared to neutrophil values:

a $P<0.001$

${ }^{b} P<0.01$. 
monocyte preparations used contained approx. 70-75\% lymphocytes. It could be that these lymphocytes contributed to the different results between monocytes and neutrophils. Therefore, monocyte-lymphocyte preparations were further purified by Percoll-gradient centrifugation. The purified preparations (58-95\% monocytes) were also stimulated with arachidonic acid and opsonized staphylococci. No differences were observed between the amount of superoxide produced by the lymphocytes-containing monocyte suspension and by the purified monocyte suspension after stimulation (data not shown).

\section{Effect of arachidonic acid on oxygen consumption by} phagocytic cells

Oxygen consumption of monocytes (containing only 5-15\% lymphocytes) and neutrophils was measured with a Clark electrode. No differences in oxygen consumption were observed when the

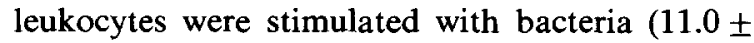
0.9 vs. $12.3 \pm 0.8 \mathrm{nmol} \mathrm{O}_{2} / 10^{6}$ cells) in the first 5

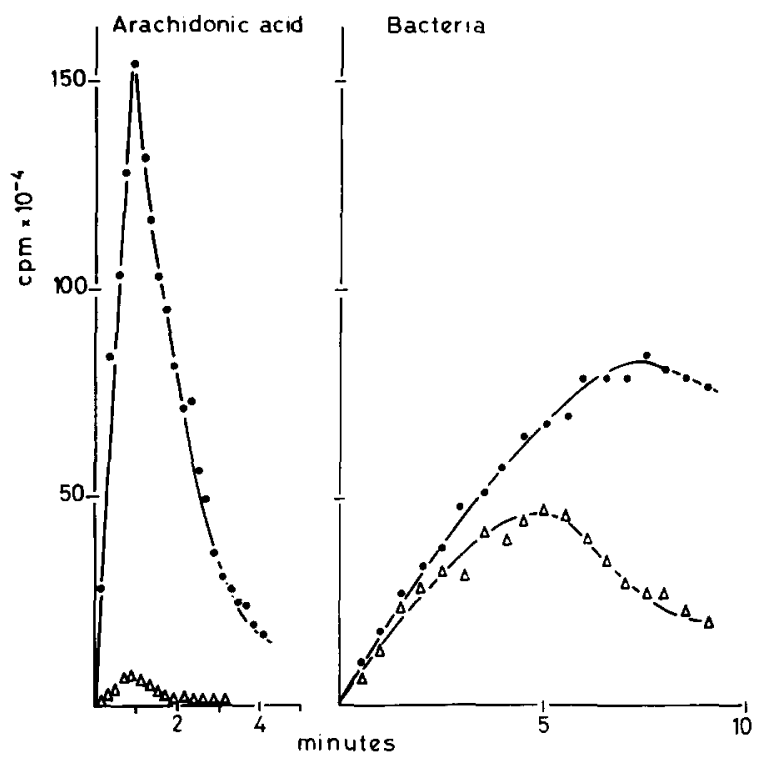

Fig. 1. Generation of chemiluminescence by polymorphonuclear leukocytes $(\bullet)$ and mononuclear phagocytes $(\Delta)$ stimulated with $S$. aureus or with arachidonic acid. Leukocytes $\left(5 \cdot 10^{6}\right)$ were incubated with $2.5 \cdot 10^{8} S$. aureus or with $160 \mu \mathrm{M}$ arachidonic acid in the presence of $0.03 \mathrm{nmol}$ luminol in a total volume of $1 \mathrm{ml}$. The generation of chemiluminescence was measured for $0.1 \mathrm{~min}$ every $12 \mathrm{~s}$ over a $5-10 \mathrm{~min}$ period in a liquid scintillation counter in out-of-incidence mode. Representative experiments of $n=7$ (arachidonic acid) and $n=3$ (bacteria). min after stimulation. However, when the cells were stimulated with arachidonic acid, a great difference between the two cell populations was observed. Monocytes consumed only $5.3 \pm 0.7$ nmol $\mathrm{O}_{2} / 10^{6}$ cells compared to $20.0 \pm 1.1 \mathrm{nmol}$ $\mathrm{O}_{2} / 10^{6}$ cells by neutrophils in the first $5 \mathrm{~min}$ after stimulation.

Effect of arachidonic acid on the generation of chemiluminescence by phagocytic cells

Monocytes generated almost no chemiluminescence when stimulated with arachidonic acid (Fig. 1). On the other hand, neutrophils generated a large amount of chemiluminescence. Arachidonicacid-treated neutrophils produced $150 \cdot 10^{4} \mathrm{cpm}$ compared to $10 \cdot 10^{4} \mathrm{cpm}$ by arachidonic-acidtreated monocytes. When these cells were stimulated by opsonized staphylococci, $100 \cdot 10^{4}$ and $50 \cdot 10^{4} \mathrm{cpm}$ were generated, respectively. No differences in chemiluminescence response between monocyte-lymphocyte suspensions and purified monocyte suspensions were observed (data not shown).

Effect of indomethacin on the metabolic burst of neutrophils

As is shown, on incubation with arachidonic acid, polymorphonuclear leukocytes produced superoxide, generated chemiluminescence and consumed oxygen. The stimulation of the cell metabolism could be reduced to $40-60 \%$ by prior incubation of the cells with indomethacin $(10 \mu \mathrm{M})$ for $10 \mathrm{~min}$ at $37^{\circ} \mathrm{C}$ (Table II). Although, less pronounced, similar effects were observed when neutrophils were incubated with lower concentrations of indomethacin $(0.1-5 \mu \mathrm{M})$.

\section{Aggregation of phagocytic cells}

Monocytes and neutrophils were incubated with arachidonic acid or opsonized bacteria, and the degree of aggregation was followed at $609 \mathrm{~nm}$ in an aggregation module. Both cell types showed a similar aggregation response when incubated with bacteria (Fig. 2). However, arachidonic-acidtreated neutrophils aggregated to a much larger degree than arachidonic-acid-treated monocytes, again indicating that the effect of arachidonic acid on polymorphonuclear leukocytes was much more pronounced than that on mononuclear phagocytes. 
TABLE II

EFFECT OF INDOMETHACIN ON THE METABOLIC BURST OF NEUTROPHILS STIMULATED WITH ARACHIDONIC ACID

$5 \cdot 10^{6}$ neutrophils were incubated with $10 \mu \mathrm{M}$ indomethacin for $10 \mathrm{~min}$ at $37^{\circ} \mathrm{C}$, whereafter $80 \mu \mathrm{M}$ arachidonic acid was added $(n=5)$. Metabolic activity of the neutrophils was studied by measuring the amount of superoxide produced, oxygen consumed and chemiluminescence generated.

\begin{tabular}{llll}
\hline & $\begin{array}{l}\text { Superoxide production } \\
\left(\mathrm{nmol} \mathrm{O}_{2}^{-} / 5 \cdot 10^{6} \text { cells } / 15 \mathrm{~min}\right)\end{array}$ & $\begin{array}{l}\text { Oxygen consumption } \\
\left(\mathrm{nmol} \mathrm{O} / 10^{6} \text { cells per } 15 \mathrm{~min}\right)\end{array}$ & $\begin{array}{l}\text { Chemiluminescence } \\
\left(\mathrm{cpm} \times 10^{-3}\right)\end{array}$ \\
\hline Control & $53 \pm 8$ & $21 \pm 4$ & $1211 \pm 157$ \\
Indomethacin & $24 \pm 5^{\mathrm{a}}$ & $11 \pm 2^{\mathrm{b}}$ & $775 \pm 87^{\mathrm{a}}$ \\
\hline
\end{tabular}

$P$ values compared to control values:

a $P<0.001$;

b $P<0.01$.

Effect of arachidonic acid on chemotactic activity of phagocytic cells

Leukocytes were incubated with 0,40 or $80 \mu \mathrm{M}$ arachidonic acid for $10 \mathrm{~min}$ at $37^{\circ} \mathrm{C}$, after which chemotaxis of the cells was measured under agarose

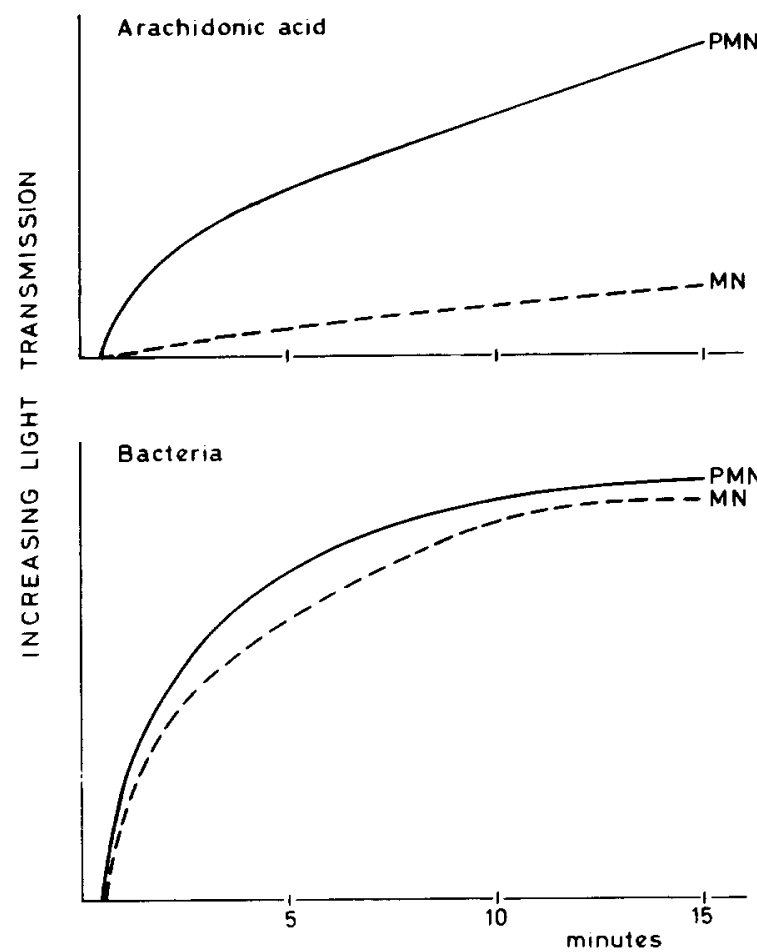

Fig. 2. Aggregation of neutrophils (PMN) and monocytes (MN) incubated with arachidonic acid or $S$. aureus. $5 \cdot 10^{6}$ leukocytes were stimulated with $160 \mu \mathrm{M}$ arachidonic acid or $2.5 \cdot 10^{8}$ of opsonized bacteria in a total volume of $0.5 \mathrm{ml}$. Aggregation was monitored by measuring the decrease in light scattering at 609 $\mathrm{nm}$. Results shown are representative of three separate experiments.
(Fig. 3). Incubating mononuclear phagocytes with arachidonic acid had no effect on the migration distance of the cells. Control cells migrated $1.64 \pm$ $0.23 \mathrm{~mm}$, and monocytes incubated with 40 or 80 $\mu \mathrm{M}$ arachidonic acid migrated $1.89 \pm 0.29$ and $1.71 \pm 0.28 \mathrm{~mm}$, respectively. In contrast, neutrophils lost their ability to migrate towards an attractant when these cells were incubated with arachidonic acid. Control cells migrated $1.86 \pm$ $0.22 \mathrm{~mm}$, cells incubated with $40 \mu \mathrm{M}$ arachidonic acid migrated $1.01 \pm 0.16 \mathrm{~mm}(P<0.001)$ and with $80 \mu \mathrm{M} 0.21 \pm 0.20 \mathrm{~mm}(P<0.001)$.

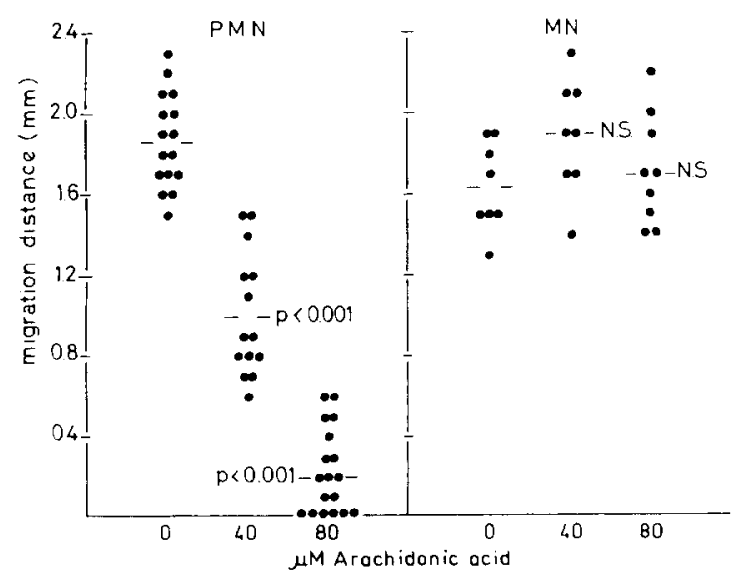

Fig. 3. Chemotaxis of polymorphonuclear leukocytes (PMN) and mononuclear phagocytes (MN) incubated with 0,40 or 80 $\mu \mathrm{M}$ arachidonic acid. Chemotaxis was performed under agarose towards zymosan-activated serum at $37^{\circ} \mathrm{C}$ for $18 \mathrm{~h}$ in a humidified atmosphere of $5 \% \mathrm{CO}_{2} / 95 \%$ air. Migration distance was measured microscopically in $\mathrm{mm}$ and directed migration was calculated as migration towards zymosan-activated serum minus spontaneous migration. N.S., not significant. 
Effect of arachidonic acid on uptake of $S$. aureus by phagocytic cells

In Fig. 4, the effect of arachidonic acid on phagocytosis of $S$. aureus by polymorphonuclear and mononuclear leukocytes is shown. The leukocytes were incubated with 0,80 or $160 \mu \mathrm{M}$ arachidonic acid for $10 \mathrm{~min}$ at $37^{\circ} \mathrm{C}$. Staphylococci were opsonized in 5\% serum and were then added to the cells. Uptake of staphylococci by neutrophils decreased as the cells were incubated with increasing amounts of arachidonic acid. When the cells were treated with $160 \mu \mathrm{M}$ arachidonic acid, only $42 \%$ of the radiolabeled bacteria were taken up, compared to $93 \%$ of staphylococci by control cells. When the neutrophils were incubated with arachidonic acid at $0^{\circ} \mathrm{C}$, no decrease in phagocytic activity could be observed. In contrast to neutrophils, no diminished phagocytic function was observed when monocytes were incubated with arachidonic acid at $37^{\circ} \mathrm{C}$ compared to untreated cells (Fig. 4).

Toxic oxygen species, produced during the incubation of neutrophils with arachidonic acid, could be responsible for the observed decreased phagocytic activity of the cells after incubation with arachidonic acid. Cells from patients with

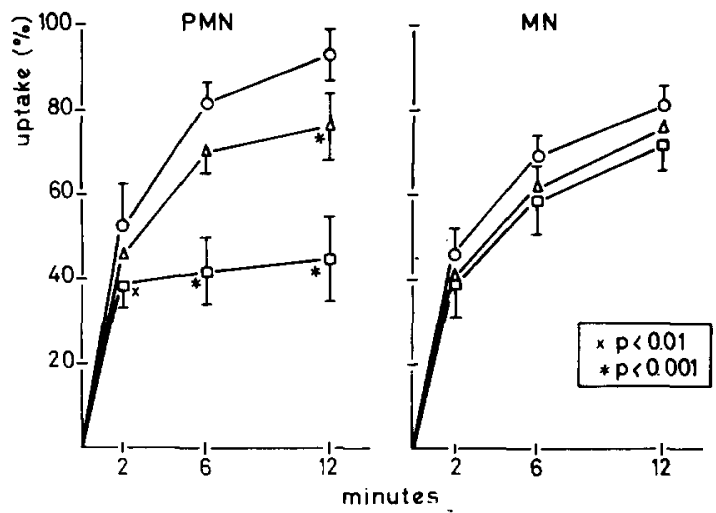

Fig. 4. Phagocytosis of $S$. aureus, opsonized in $5 \%$ serum, by monocytes (MN) and neutrophils (PMN) incubated with $0(O)$, $80(\Delta)$ or 160 (口) $\mu \mathrm{M}$ arachidonic acid. $1 \cdot 10^{6}$ leukocytes were mixed with $1 \cdot 10^{7}$ opsonized radiolabeled bacteria and incubated for 2,6 and $12 \mathrm{~min}$ at $37^{\circ} \mathrm{C}$. Unassociated staphylococci were removed by washings and centrifugations $(160 \times \mathrm{g}$ for $5 \mathrm{~min})$. From the amount of cell-associated radioactivity the uptake of $S$. aureus was calculated. Data represent $n=7$ for polymorphonuclear and $n=3$ for mononuclear leukocytes.

chronic granulomatous disease do not produce oxygen species [4], and these cells were less affected by incubation with arachidonic acid than

\section{TABLE III}

EFFECT OF ARACHIDONIC ACID ON PHAGOCYTOSIS OF BACTERIA BY CONTROL AND CHRONIC GRANULOMATOUS DISEASE NEUTROPHILS AND IN THE PRESENCE OF VARIOUS OXYGEN SCAVENGERS OR INDOMETHACIN

$1 \cdot 10^{6}$ neutrophils were incubated with arachidonic acid at $37^{\circ} \mathrm{C}$ with or without oxygen scavengers or indomethacin ( $n=3$ ). After 10 min, preopsonized staphylococci were added to measure the phagocytic capacity of the cells. n.d., not done.

\begin{tabular}{|c|c|c|c|c|}
\hline & \multicolumn{4}{|c|}{ \% uptake of bacteria in the presence of arachidonic acid at $(\mu \mathrm{M})$} \\
\hline & 0 & 80 & 160 & 320 \\
\hline Control neutrophils & $93 \pm 6$ & $76 \pm 8$ & $45 \pm 10$ & $3 \pm 2$ \\
\hline Chronic granulomatous disease neutrophils & $91 \pm 5$ & $93 \pm 6^{a}$ & $76 \pm 7^{d}$ & $5 \pm 4$ \\
\hline Ferricytochrome $c(1.5 \mathrm{mM})$ & $90 \pm 8$ & $81 \pm 8$ & $66 \pm 9^{c}$ & $25 \pm 11^{b}$ \\
\hline Superoxide dismutase $(1.5 \mathrm{mg} / \mathrm{ml})$ & $86 \pm 8$ & $52 \pm 10^{a}$ & $47 \pm 8$ & $26 \pm 12^{b}$ \\
\hline Catalase $(0.5 \mathrm{mg} / \mathrm{ml})$ & $85 \pm 7$ & $46 \pm 10^{b}$ & $25 \pm 8^{a}$ & $1 \pm 3$ \\
\hline Superoxide dismutase + catalase $(1.5$ and $0.5 \mathrm{mg} / \mathrm{ml})$ & $88 \pm 6$ & $56 \pm 7^{a}$ & $39 \pm 9$ & n.d. \\
\hline Thiourea $(50 \mathrm{mM})$ & $88 \pm 10$ & $66 \pm 8$ & $48 \pm 8$ & $2 \pm 4$ \\
\hline Cyanide (10 mM) & $86 \pm 9$ & $78 \pm 8$ & $76 \pm 6^{d}$ & n.d. \\
\hline Indomethacin $(20 \mu \mathrm{M})$ & $89 \pm 5$ & $80 \pm 5$ & $63 \pm 7^{b}$ & $25 \pm 7^{d}$ \\
\hline
\end{tabular}

$P$ values compared to control values:

a $P<0.05$;

b $P<0.02$;

c $P<0.01$

d $P<0.005$. 
control neutrophils (Table III). Polymorphonuclear leukocytes were also incubated with arachidonic acid in the presence of agents which scavenge oxygen species $\left(10 \mathrm{~min}\right.$ at $\left.37^{\circ} \mathrm{C}\right)$, whereafter phagocytosis was measured (Table III). Ferricytochrome $c$ and cyanide prevented the effect of arachidonic acid on phagocytosis, and superoxide dismutase had only a preventive effect when high amounts of arachidonic acid were present. The hydroxylscavenger thiourea had no effect, and catalase even enhanced the effect of arachidonic acid on the phagocytic capacity.

When neutrophils were incubated with arachidonic acid in the presence of indomethacin, the decrease in phagocytic activity was less pronounced than after incubation with arachidonic acid only (Table III).

\section{Enzyme release from neutrophils}

Polymorphonuclear leukocytes were incubated with arachidonic acid or with opsonized $S$. aureus for $10 \mathrm{~min}$ at $37^{\circ} \mathrm{C}$, whereafter the amounts of $\beta$-glucuronidase and lactate dehydrogenase released were measured (Table IV). Neutrophils incubated with bacteria released $\beta$-glucuronidase, but no release of the cytosol enzyme lactate dehydrogenase was observed. When the cells were in-

\section{TABLE IV}

\section{EFFECT OF DIFFERENT STIMULI ON THE ENZYME RELEASE FROM NEUTROPHILS}

$5 \cdot 10^{6}$ leukocytes were incubated with the different agents in a total volume of $1 \mathrm{ml}$ for $10 \mathrm{~min}$ at $37^{\circ} \mathrm{C}$. Enzyme determinations took place on the cell fractions ( $n=5$ ). Lactate dehydrogenase was determined by measuring the reduction of NADH by pyruvate spectrophotometrically at $366 \mathrm{~nm}$. $\beta$-Glucuronidase activity was assayed with $p$-nitrophenyl- $\beta$-D-glucuronide as substrate.

\begin{tabular}{|c|c|c|}
\hline \multirow[t]{2}{*}{ Agent } & \multicolumn{2}{|c|}{ Enzyme release (\% of total activity) } \\
\hline & $\begin{array}{l}\text { lactate } \\
\text { dehydrogenase }\end{array}$ & $\beta$-glucuronidase \\
\hline Control & $5 \pm 5$ & $2 \pm 6$ \\
\hline $2.5 \cdot 10^{8} S$. aureus & $3 \pm 6$ & $35 \pm 3^{b}$ \\
\hline $40 \mu \mathrm{M}$ arachidonic acid & $1 \pm 7$ & $1 \pm 7$ \\
\hline $80 \mu \mathrm{M}$ arachidonic acid & $6 \pm 8$ & $2 \pm 7$ \\
\hline $160 \mu \mathrm{M}$ arachidonic acid & $12 \pm 6^{a}$ & $8 \pm 9$ \\
\hline
\end{tabular}

$P$ values compared to control values:

a $P<0.05$;

b $P<0.001$.
TABLE $V$

MALONYLDIALDEHYDE DETERMINATIONS OF NEUTROPHILS INCUBATED WITH ARACHIDONIC ACID OR STAPHYLOCOCCI

$4 \cdot 10^{7}$ neutrophils were mixed with the different agents in a total volume of $1 \mathrm{ml}$ and incubated for $1 \mathrm{~h}$ at $37^{\circ} \mathrm{C}$. The reaction was stopped by adding a trichloroacetic acid-hydrochloride acid mixture. After mixing with thiobarbiturate and heating for $15 \mathrm{~min}$ at $37^{\circ} \mathrm{C}$ the absorption was determined at $530 \mathrm{~nm}(n=4)$.

\begin{tabular}{ll}
\hline Agent & $E_{530} \mathrm{~nm}$ \\
\hline Control & $0.022 \pm 0.014$ \\
$40 \mu \mathrm{M}$ arachidonic acid & $0.035 \pm 0.004$ \\
$80 \mu \mathrm{M}$ arachidonic acid & $0.064 \pm 0.004^{\mathrm{a}}$ \\
$160 \mu \mathrm{M}$ arachidonic acid & $0.159 \pm 0.048^{\mathrm{a}}$ \\
$4 \cdot 10^{8}$ S. aureus & $0.044 \pm 0.003$ \\
$1 \cdot 10^{9}$ S. aureus & $0.080 \pm 0.004^{\mathrm{a}}$ \\
$2 \cdot 10^{9}$ S. aureus & $0.152 \pm 0.020^{\text {a }}$ \\
\hline
\end{tabular}

a $P<0.001$ compared to control values.

cubated with arachidonic acid, no release of enzymes could be observed. Only neutrophils incubated with $160 \mu \mathrm{M}$ arachidonic acid showed a slight decrease in the total amount of lactate dehydrogenase. When the cells were incubated for 30 min with $160 \mu \mathrm{M}$ arachidonic acid, a decrease in the total amount of lactate dehydrogenase and $\beta$-glucuronidase could be observed (15-25\% release), indicating that the plasmamembrane of neutrophils could be damaged after incubation with high amounts of arachidonic acid for a long period of time.

\section{Lipid peroxidation by neutrophils}

The oxidative degradation of unsaturated fatty acids was followed by the determination of the amount of malonyldialdehyde, a metabolite formed during lipid peroxidation by oxygen metabolites $[34,35]$. Polymorphonuclear leukocytes were incubated with different amounts of arachidonic acid and opsonized staphylococci and a dose-dependent result was observed (Table V). When more arachidonic acid or bacteria were used, a higher amount of malonyldialdehyde was formed.

\section{Discussion}

When exogenous arachidonic acid was added to phagocytic cells, different effects were observed. 
High levels of oxygen consumption, superoxide production and chemiluminescence generation were measured when neutrophils were incubated with arachidonic acid. In contrast, monocytes were less able to induce a burst in oxidative metabolism after incubation with arachidonic acid. Also, arachidonic-acid-treated neutrophils aggregated to a much higher degree than incubated monocytes. After exposure to arachidonic acid, phagocytosis of bacteria and chemotaxis towards an attractant by neutrophils was greatly diminished. However, exogenous arachidonic acid in the concentrations tested had no effects on phagocytic and chemotactic activity of mononuclear phagocytes.

The decreased chemotactic and phagocytic activity of neutrophils observed after incubation with arachidonic acid could be due to inhibitory action of metabolic derivatives of arachidonic acid. Addition of arachidonic acid to neutrophils results in the formation of mono- and dihydroxyeicosatetraenoic acids $[16,36,37]$ which can be metabolized to leukotrienes and prostaglandins. Leukotriene $\mathrm{B}_{4}$ is a chemokinetic and aggregating substance released from activated neutrophils $[8,15$, 36]. Stimulated neutrophils also produce thromboxane $A_{2}$, which enhances the aggregation and adhesiveness of the cells to nylon wool [17]. The production of these aggregating and adherence-increasing agents could result in diminished chemotaxis towards zymosan-activated serum and a decreased phagocytic capacity of polymorphonuclear leukocytes. Also, the stimulation of neutrophil metabolism by arachidonic acid was reduced $40-60 \%$ by prior incubation of the neutrophils with indomethacin. Indomethacin is an inhibitor of prostaglandin synthesis [38]. Also, the decreasing effect on phagocytosis was partly abolished by indomethacin. Andersen et al. [39] found that indomethacin inhibits the chemiluminescence response, but it failed to block the oxygen consumption and glucose metabolism after arachidonic acid stimulation. Yoshimoto et al. [20] and Badwey et al. [19] also did not observe any effect of indomethacin on the metabolic response of neutrophils to arachidonic acid. A possible reason for these differences could be their time of incubation with indomethacin, before adding arachidonic acid, which was shorter than in our experiments.
An other explanation for the inhibitory action of arachidonic acid on neutrophil function could be the injurious effect of toxic oxygen species. These oxygen species were indeed produced by the cells during incubation with arachidonic acid, as we demonstrated by the enhanced superoxide production and chemiluminescence generation. Cellular oxygen metabolism is involved in the process of lipidperoxidation [35]. This process has been shown to result in severe damage to cellular membranes [40]. That arachidonic acid was capable of initiating lipidperoxidation was determined by the production of malonyldialdehyde, a secondary product of lipidperoxidation. Also, the aggregation experiments indicated that the cell membrane structure of the neutrophils was altered. Moreover, cells from a patient with chronic granulomatous disease were less sensitive for the decreasing activity of arachidonic acid on phagocytic cell function. These cells are able to metabolize arachidonic acid into hydroxyeicosatetraenoic acids and leukotrienes [41], but are not able to inactivate these biological mediators by an oxidative mechanism [42]. Scavengers of oxygen species were able to interfere with the effect of arachidonic acid on phagocytosis; cyanide, cytochrome $c$ and superoxide dismutase prevented the effect of arachidonic acid on phagocytic cell activity. Cyanide, like other heme inhibitors, blocks the activity of myeloperoxidase and catalase. This results in an accumulation of $\mathrm{H}_{2} \mathrm{O}_{2}$ [43]. The excess of $\mathrm{H}_{2} \mathrm{O}_{2}$, and also cyanide itself, could possibly oxidize arachidonic acid, which results in a diminished amount of arachidonic acid available to induce phagocytic disfunction. The effect of arachidonic acid on phagocytosis was totally absent at an incubation temperature of $0^{\circ} \mathrm{C}$, indicating that an active metabolism of the neutrophils is needed for the observed decreasing activity of arachidonic acid.

As mentioned, the effects of arachidonic acid on the phagocytic cell function are specific for neutrophils. After incubation with arachidonic acid, monocytes produced superoxide, generated chemiluminescence and consumed oxygen to a much lesser extent as compared to neutrophils. Phagocytosis and killing of bacteria by human polymorphonuclear and mononuclear leukocytes are similar $[1,2,22]$, but the metabolic response of 
monocytes following phagocytosis of particles is somewhat less than that of neutrophils [44]. However, the difference in the extent of the metabolic burst upon stimulation with arachidonic acid between monocytes and neutrophils was much larger than that observed after stimulation with opsonized particles. It remains possible that incubation of monocytes with arachidonic acid did not lead to peroxidation and that no membrane damage occurred, so that the phagocytic and chemotactic activity of the monocytes remained unaltered. An other possibility is that arachidonic-acid-treated monocytes did not generate arachidonic acid metabolites which potentially affect phagocytic cell function. To test this hypothesis, further experiments have to be performed to examine whether there are differences in arachidonic acid metabolism between these two phagocytic cell types.

\section{Acknowledgement}

We thank Dr. Christina M.J.E. VandenbrouckeGrauls for her helpful discussions during the preparation of this manuscript.

\section{References}

1 Babior, B.M. (1978) N. Engl. J. Med. 298, 659-668, 721-725

2 Stossel, T.P. (1974) N. Engl. J. Med. 290, 717-723, 774-780, 833-839

3 Quie, P.G., Mills, E.L. and Holmes, B. (1977) Prog. Hematol. $10,193-210$

4 Klebanoff, S.J. and Clark, R.A. (1978) The Neutrophil: Function and Clinical Disorders, pp. 283-408, Elsevier/North-Holland, Amsterdam

5 Smolen, J.E. and Shohet, S.B. (1974) J. Clin. Invest. 53 , $726-734$

6 Higgs, G.A., McCall, E. and Youlten, L.J.F. (1975) Br. J. Pharmacol. 53, 539-546

7 Humes, J.L., Bonney, R.J., Pelus, L., Dahlgren, M.E., Sadowski, S.J., Kuehl, F.A., Jr. and Davies, P. (1977) Nature (Lond.) 269, 149-151

8 Palmer, R.M.J. and Salmon, J.A. (1983) Immunology 50, 65-73

9 Bonney, R.J., Naruns, P., Davies, P. and Humes, J.L. (1979) Prostaglandins 18, 605-616

10 Scott, W.A., Pawlowski, N.A., Murray, H.W., Andreach, M., Zrike, J. and Cohn, Z.A. (1982) J. Exp. Med. 155, 1148-1160

11 Stenson, W.F. and Parker, C.W. (1979) J. Clin. Invest. 64, 1457-1465

12 Flower, R.J. and Blackwell, G.J. (1976) Biochem. Pharmacol. $25,285-291$

13 Kuehl, F.A., Jr. and Egan, R.W. (1980) Science 210, 978-984

14 Borgeat, P. and Sirois, P. (1981) J. Med. Chem. 24, 121-126
15 Ford-Hutchinson, A.W., Bray, M.A., Doig, M.V., Shipley, M.E. and Smith, M.J.H. (1980) Nature (Lond.) 286, 264-265

16 Goetzl, E.J. and Sun, F.F. (1979) J. Exp. Med. 150, 406-411

17 Spagnuolo, P.J., Ellner, J.J., Hassid, A. and Dunn, M.J. (1980) J. Clin. Invest. 66, 406-414

18 O'Flaherty, J.T., Showell, H.J., Becker, E.L. and Ward, P.A. (1979) Am. J. Pathol. 95, 433-444

19 Badwey, J.A., Curnutte, J.T. and Karnovsky, M.L. (1981) J. Biol. Chem. 256, 12640-12643

20 Yoshimoto, S.. Yoshimoto. T. and Tsubura, E. (1982) Biochem. Biophys. Res. Commun. 107, 779-784

21 Nijkamp, F.P., Moncada, S., White, H.L. and Vane, J.R. (1977) Eur. J. Pharmacol. 44, 179-186

22 Verbrugh, H.A., Peters, R., Peterson, P.K. and Verhoef, J. (1978) J. Clin. Pathol. 31, 539-545

23 Böyum, A. (1968) Scand. J. Clin. Lab. Invest. 21, Suppl. 97, $77-89$

24 Gutierrez, C., Bernabe, R.R., Vega, J. and Kreisler, M. (1979) J. Immunol. Methods 29, 57-63

25 Stjernholm, R.L., Allen, R.C., Steele, R.H., Waring, W.W and Harris, J.A. (1973) Infect. Immun. 7, 313-314

26 Henricks, P.A.J., Van der Tol, M.E. and Verhoef, J. (1984) Immunology 52,671-678

27 Babior, B.M., Kipnes, R.S. and Curnutte, J.T. (1973) J Clin. Invest. 52, 741-744

28 Weening, R.S., Roos, D. and Loos, J.A. (1974) J. Lab. Clin. Med. 83, 570-577

29 Verhoef, J., Peterson, P.K. and Quie, P.G. (1977) J. Immunol. Methods 14, 303-311

30 Nelson, R.D., Quie, P.G. and Simmons, R.L. (1975) J. Immunol. 115, 1650-1656

31 Henricks, P.A.J., Van der Tol, M.E., Thyssen, R.M.W.M., Van Asbeck, B.S. and Verhoef, J. (1983) Infect. Immun. 41 294-301

32 Barrett, A.J. (1972) in Lysosomes. A Laboratory Handbook (Dingle, J.T., ed.), pp. 46-135, Elsevier/North-Holland, Amsterdam

33 Worthington Enzyme Manual (1977) (Decker, L.A., ed.), pp. 19-22, Worthington Biochemical Corporation, Freehold

34 Smith, J.B., Ingerman, C.M. and Silver, M.J. (1976) J. Lab. Clin. Med. 88, 167-172

35 Stossel, T.P., Mason, R.J. and Smith, A.L. (1974) J. Clin. Invest. 54, 638-645

36 Borgeat, P. and Samuelsson, B. (1979) Proc. Natl. Acad. Sci. USA $76,2148-2152$

37 O'Flaherty, J.T., Thomas, M.J., Cousart, S.L., Salzer, W.L. and McCall, C.E. (1982) J. Clin. Invest. 69, 993-998

38 Vane, J.R. (1971) Nat. New Biol. 231, 232-235

39 Andersen, B.R., Amirault, H.J. and LeBreton, G.C. (1981) Prostaglandins 22, 469-484

40 Badwey, J.A. and Karnovsky, M.L. (1980) Annu. Rev. Biochem. 49, 695-726

41 Smith, D.M., Walsh, C.E., DeChatelet, L.R. and Waite, M. (1983) Infect. Immun. 40, 1230-1233

42 Henderson, W.R. and Klebanoff, S.J. (1983) J. Biol. Chem 258, 13522-13527

43 Nauseef, W.M., Metcalf, J.A. and Root, R.K. (1983) Blood 61, 483-492

44 Nelson, R.D., Mills, E.L., Simmons, R.L. and Quie, P.G. (1976) Infect. Immun. 14, 129-134 